\title{
Bimbingan Keagamaan melalui Program Mahkamah untuk Meningkatkan Kedisiplinan Santri
}

\author{
Nisa Rahmatunisa* \\ Jurusan Bimbingan dan Konseling Islam, UIN Sunan Gunung Djati Bandung \\ *Email : nisarahmatunisa@gmail.com
}

\begin{abstract}
The purpose of this research is to get an idea of how the circumstances of students at Ma'bad, then menggarambarkan how process guidance conducted Court in boarding school and described the outcome of the guidance is done justice program that on its own. The research was conducted using qualitative approach method of descriptive studies. As for the data collection technique does is observation, interviews, documentation and cross check see directly when religious guidance takes place at the Office of the Court. The results of this research are the students break the rules $M a^{\prime}$ bad gets special treatment i.e. the form of religious guidance conducted by the Court, then the results from doing religious guidance through the program the Court pointed out that the students got religious guidance over the violations that he did, and the results are good, but the results of this study stated santri diversity results from the guidance include: students are wary after gaining guidance. Students who keep breaking and not feel the santri deterrent and deterrent but still sometimes breached.
\end{abstract}

Keywords: Religious Guidance; The Court; Discipline; Adolescent (Santri)

\section{ABSTRAK}

Tujuan penelitian ini adalah untuk mendapatkan gambaran bagaimana keadaan santri di Ma'had, kemudian menggarambarkan bagaimana proses bimbingan yang dilakukan mahkamah di Pesantren dan menggambarkan hasil dari bimbingan yang dilakukan program mahkamah itu sendiri. Penelitian ini dilakukan dengan menggunakan pendekatan kualitatif metode studi deskriptif. Adapun teknik pengumpulan data yang dilakukan adalah observasi, wawancara, dokumentasi dan cross check melihat secara langsung ketika bimbingan keagamaan berlangsung di kantor mahkamah. Hasil penelitian ini adalah santri yang melanggar aturan Ma'had mendapat perlakuan khusus yakni berupa 
bimbingan keagamaan yang dilakukan oleh mahkamah, kemudian hasil dari melakukan bimbingan keagamaan melalui program mahkamah menunjukkan bahwa santri yang mendapat bimbingan keagamaan atas pelanggaran yang dilakukannya beragam dan hasilnya baik, namun hasil dari penelitian ini menyatakan keberagaman santri dari hasil bimbingan tersebut diantaranya: santri yang jera setelah mendapat bimbingan. Santri yang tetap melanggar dan tidak merasa jera dan santri yang jera namun masih terkadang melanggar.

Kata Kunci : Bimbingan Keagamaan; Mahkamah; Kedisiplinan;Santri

\section{PENDAHULUAN}

Pesantren adalah lembaga dakwah Islam yang didirikan untuk memahami, menghayati dan mengamalkan ajaran Islam dengan menekankan pentingnya moral Islam sebagai pedoman hidup bermasyarakat sehari-hari.Istilah pesantren telah akrab pemakaiannya di kalangan masyarakat untuk membedakan antara pendidikan Islam dan pendidikan umum. Namun zaman sekarang telah banyak ditemukan berbagai kasus dalam pesanren dan salah satunya ialah perkara masalah dalam penghukuman santri untuk mendidik rasa kedisiplinan terhadap santrinya, ada beberapa orang tua santri yang merasa tidak nyaman dengan hukuman yang didalamnya terdapat kekerasan fisik.

Darul Arqam merupakan pondok pesantren Muhammadiyah di Garut dengan model pesantren modern dan tidak berbentuk pesantren salafi, namun Darul Arqam ini sama seperti pesantren-pesantren pada umumnya yang memiliki kyai (ustadz), santri, mempelajari beberapa kitab, santri yang modok dan tinggal di asrama Darul Arqam juga mengajarkan ajaran islam lainnya terutama moral. Darul Arqam termasuk pesantren yang terkenal, dan bukan hanya di daerah Garut saja tapi sudah terkenal ke berbagai daerah bahkan terkenal di luar pulau Jawa, hal ini terbukti dengan santri yang bersekolah dan mondok disana.

Hasil dari survei dan wawancara (Ibu Aas: 2018) diketahui santri yang bersekolah dan mondok di Darul Arqam ini berkisar umur 13-17 tahun, artinya santri yang mondok dan bersekolah di Darul Arqam ini termasuk ke tahap fase remaja dan pada periode ini adalah proses perubahan-perubahan perilaku, emosi dan psikologis.

Remaja identik memiliki sifat khas yaitu mempunyai rasa ingin tahu yang besar, menyukai petualangan dan tantangan serta cenderung berani menanggung resiko atas perbuatannya tanpa didahului oleh pertimbangan yang matang. Apabila keputusan yang diambil dalam menghadapi konflik tidak tepat, mereka akan jatuh ke dalam perilaku beresiko dan mungkin harus menanggung akibat jangka pendek dan jangka panjang dalam berbagai masalah kesehatan fisik maupun psikososial. Sifat dan perilaku beresiko pada remaja tersebut 
memerlukan tersedianya pelayanan untuk pengembangan diri. Masa remaja merupakan masa transisi dalam rentang kehidupan manusia, menghubungkan masa kanak-kanak dan masa dewasa (Santrock, 2003).

Darul Arqam merupakan pesantren yang menjadi sebuah lingkungan sosial dengan santri yang berjumlah 1087 orang bertempat tinggal di lingkungan yang sama, asrama yang sama, dapur yang sama bahkan toilet yang sama.

Perkembangan anak dipengaruhi oleh dua faktor utama, yakni faktor bawaan dan faktor lingkungan. Faktor bawaan atau keturunan (hereditas) merupakan faktor pertama yang memengaruhi tumbuh kembang anak. Faktor lingkungan dapat diartikan sebagai peristiwa, situasi dan kondisi di luar individu yang secara langsung maupun tidak langsung memengaruhi tumbuh kembang anak atau perkembangan individu. Lingkungan fisik adalah segala sesuatu yang bersifat fisik yang ada di sekutar individu seperti keadaan rumah, pekarangan, sawah, tanah, air dan sebagainya. Sedangkan lingkungan sosial adalah meliputi seluruh manusia dengan berbagai interaksinya yang menciptakan lingkungan pergaulan yang khas. Lingkungan sosial merupakan lingkungan masyarakat, di mana dalam lingkunga masyarakat ini terdapat interaksi individu satu dengan individu lain.

Disinilah yang dimaksud dimana lingkungan sosial merupakan salah satu sebuah faktor yang memengaruhi naikya emosional seorang remaja (santri). Faktor lingkungan sosial yang akan memengaruhi meningkatnya emosional pada santri berujung pada perilaku menyimpang yang dilakukan oleh santri. Terdapat berbagai macam bentuk dari perilaku menyimpang, dari hasil wawancara dengan salah satu pembina santri Darul Arqam ada beberapa perilaku yang melanggar aturan pondok terdapat pada santri Darul Arqam, namun yang dimaksud penyimpangan disini tentunya ada batasan tertentu karena Ma'had Darul Arqam ini punya aturan dan tatatertib yang tertulis. Adapunn aturan-aturan yang ada di Ma'had Darul Arqam diantaranya; berambut panjang bagi putra, keluar tanpa izin, tidak sholat berjamaah, bercelana pendek, dilarang membawa elektronik, berkholwat, berkelahi, mencuri, merokok, bertato, bolos sekolah melakukan penganiayaan dan lainnya.

Dari pelanggaran yang santri lakukan maka Ma'had tersebut membuat program yang dinamakan mahkamah, dimana program tersebut dibuat dengan maksud untuk membuat santri mampu menjadi remaja yang disiplin. Mahkamah yang terdapat di Ma'had ini adalah bagian dari BK (Bimbingan Konseling) yang ada di Ma'had. Mahkamah sendiri mempunyai aturan dan punishment hukuman yang tercatat dan tertera di dalam buku pegangan santri. Aturan dan hukuman yang terdapat di mahkamah merupakan hasil dan keputusan bersama seluruh aparatur Ma'had. Hukuman yang diberikan kepada santri berupa bimbingan keagamaan, seperti: sholat berjamaan di shad pertama, tahfidz mufradat, menulis 
Al-Quran, kultum, adzan di tempat umum. Maksud dan tujuan adanya mahkamah tersebut tidak lain untuk membuat santri menjadi disiplin. Namun dengan adanya program mahkamah ini santri masih ada saja yang melanggar aturan pondok.

Seringkali santri yang mendapatkan bimbingan di Mahkamah karena telah melanggar aturan Ma'had, adapun pelanggaran yang sering dilakukan santri ialah pelnggaran ringan, seperti: telat datang ke Ma'had, bolos sekolah, tidak sholat berjama'ah, berpakaian tidak selayaknya santri, tidak izin keluar Ma'had.

Penelitian terdahulu tentang kedisiplinan antara lain dilakukan oleh Octaviani, E.,D., dkk (2011:1) dengan judul Religiusitas Dan Kedisiplinan Pada Anggota Polri. Penelitian ini sasarannya adalah anggota polisi sedangkan penelitian penulis sasarannya mahasiswa, kajian nya pun berbeda yaitu untuk mengukur seberapa besar pengaruh bimbingan keagamaan dalam meningkatkan kedisiplinan siswa.

Penelitian Mustafidah, dkk. (2008). Yang berjudul Representasi Kasus Menggunakan Inductive Retrieval Dengan Algoritma C4.5 Pada Kasus Klasifikasi Prestasi Mahasiswa Berdasarkan Nem, Tingkat Kedisiplinan, dan Motivasi juga memiliki kajian yang berbeda yaitu lebih ke mengukur klasfikasi kedisiplinan mahasiswa. Sedangkan penelitian Yuliejantiningsih,Y., (2012). Yang berjudul Pengaruh Fungsi Pengendalian Oleh Kepala Sekolah Terhadap Disiplin Siswa fokusnya adalah pengendalian kepala sekolah dan sasarannya adalah siswa.

Adapun penelitian terdahulu tentang bimbingan keagamaan antara lain, Penelitian Kusnadi, Edy.(2014). Berjudul Pola Bimbingan Konseling Agama Islam Pada Pasien Rawat Inap. Penelitian Haderani, H., dkk.,(2014). Berjudul Peran Guru Pendidikan Agama Islam dalam Kegiatan Bimbingan Keagamaan pada Sekolah Menengah Pertama Negeri 23 Banjarmasin. Penelitian Sugiyanto, Zaenal, Suharyo. (2011) Berjudul Analisis Praktik Pendidikan Kesehatan Reproduksi Remaja Oleh Guru Bimbingan dan Konseling pada SMP yang Berbasis Agama. Perbedaan penelitian penelitian tersebut dengan penelitian peneliti adalah dari segi objeknya.

Dengan uraian tersebut maka peneliti memiliki tujuan untuk mengetahui bagaimana keadaan santri Darul Arqam, proses mahkamah dan mengetahui hasil dari program mahkamah tersebut. Adapun metode yang digunakan peneliti yaitu metode deskriptif melalui pendekatan kualitatif.

\section{LANDASAN TEORITIS}

Bimbingan dalam istilah lain disebut guidance. Kata guidance adalah dari kata kerja to guide, artinya, membimbing, menuntun atau membantu orang lain yang membutuhkan. Sesuai dengan istilahnya, maka secara umum bimbingan dapat diartikan sebagi suatu bantuan atau tuntunan (Saepulrohim, 2016:2) 
Bimbingan keagamaan adalah segala kegiatan yang dilakukan oleh seseorang dalam rangka memberikan bantuan kepada orang lain yang mengalami kesulitan-kesulitan ruhaniah dalam lingkungan hidupnya agar orang tersebut mampu mengatasinya sendiri karena timbul kesadaran dan penyerahan diri terhadap kekuasaan tuhan yang Maha Esa, sehingga timbul pada diri pribadinya suatu cahaya harapan kebahagiaan hidup masa sekarang dan masa depannya (Amin, $2013: 19$ )

Bimbingan keagamaan menjadi sangat urgen bagi generasi penerus bangsa. Khusunya untuk para santri yang memiliki perilaku negatif agar dapat merubah perilakunya dengan baik. Sebagai manusia yang memiliki akal untuk berpikir, santri ini layak untuk mendapatkan bimbingan agama. Manusia jelas memiliki derajat yang lebih tinggi dibandingkan hewan ataupun makhluk lainnya, perbedaannya terletak pada akal.

Bimbingan adalah bantuan yang diberikan oleh orang yang ahli, kepada seorang atau beberapa individu, baik anak-anak, remaja maupun dewasa. Dalam bimbingan mengandung aspek yang penting, diantaranya: 1) Bimbingan merupakan proses pemberian bantuan, 2) Bimbingan dilakukan oleh orang yang ahli, 3) Bimbingan diberikan kepada seorang atau beberapa individu, baik anakanak, remaja maupun dewasa, 4) Bimbingan diorientasikan untuk mengembangkan kemampuan individu Prayitno (2004 : 99).

Faqih (2001 : 62-63) Berdasarkan pengertian dan problem-problem yang mungkin muncul dalam kehidupan keagamaan, maka tujuan bimbingan dan konseling keagamaan islami adalah, sebagai berikut:

Pertama, Membantu individu/kelompok individu mencegah timbulnya masalah-masalah dalam kehidupan keagamaan, antara lain dengan cara: 1) Membantu individu menyadari fitrah manusia, 2) Membantu individu mkengambangkan fitrahnya (mengaktualisasikannya), 3) Membantu individu memahami dan menghayati ketentuan dan petunjuk Allah dalam kehidupan keagamaan, 4) Membantu individu menjalankan ketentuan dan petunjuk Allah mengenai kehidupan keagamaan.

Kedua, Membantu individu/kelompok individu memecahkan masalah yang berkaitan dengan kehidupan keagamaannya, antara lain dengan cara: 1) Membantu individu memahami problem yang dihadapinya, 2) Membantu individu memahami kondisi dan situasi dirinya dan lingkungannya, 3) Membantu individu memahami dan menghayati berbagai cara untuk mengatasi problem kehidupan keagamaannya sesuai dengan syari'at islam, 4) Membantu individu menetapkan pilihan upaya pemecahan problem keagamaan yang dihadapi.

Bimbingan keagamaan yang diberikan di Ma'had Darul Arqam ini termasuk kedalam irsyad. Karena irsyad Islam lebih mengarah kepada proses internalisasi dan transmisi ajaran Islam. Fokus kegiatannya dapat berupa : (1) 
ibda bi al-nafs, dzikr Allah, du'a, wiqâyat al-nafs, tazkiyyat al-nafs, shalat dan shaum ; (2) ta'lim, tawjih, mau'izhah dan nashihah ; (3) Isytisyfa.

Landasan (fondasi atau dasar pijak) utama bimbingan dan konseling islami adala Al-Quran dan Sunnah Rasul, sebab keduanya merupakan sumber dari segala sumber pedoman kehidupan umat islam.

Jika Al-Quran dan Sunnah Rasul merupakan landasan utama yang dilihat dari sudu asal-usulnya, merupakan landasan, "naqliyah" maka ada landasan lain yang digunakan oleh bimbingan dan konseling islami yang sifatnya "aqliyah" adalah filsat dan ilmu. Hal ini filsafat islami dan ilmu atau landasan ilmiah yang sejalan dengan ajaran islam (Faqih, 2001 : 5-6).

Metode yang dapat dilakukan dalam melakukan bimbingan keagamaan terbagi menjadi enam, yaitu: 1) Metode Interview (Wawancara), informasi merupakan suatu alat untuk memperoleh fakta/data/informasi dari konseli secara lisan, yang kemudian terjadi pertemuan empat mata dengan tujuan mendapatkan data yang diperlukan untuk bimbingan. Fakta psikologis yang menyangkut konseli sangat diperlukan untuk pemberian layanan bimbingan, 2) Bimbingan Kelompok, dengan bimbingan kelompok pembimbing dan konseling akan dapat mengembangakan sikap sosia, sikap memahami peranan konseli dalam lingkungannya menurut penglihatan orang lain dalam kelompok itu. Hal ini dilakukan unuk pencipaan situasi dan kondisi kebersamaan hak secara keterikatan satu sama lain, 3) Client Centered Method (Metode yang Dipusattkan pada Keadaan Klien), dalam metode ini terdapat dasar pandangan bahwa klien sebagai makhluk yang bulat yang memiliki kemampuan berkembang sendiri dan sebagai pencari kemantapan diri sendiri, 4) Directive Counseling, directive counseling sebenarnya merupaka bentuk psikoterapi yang paling sederhana, karena konselor atas dasar metode ini secara langsung memberikan jawaban-jawaban terhadap problem yang oleh klien disadari menjadi sumber kecemasannya, 5) Eductive Method (Metode Pencerahan), metode ini sebenarnya hampir sama dengan metode client-centered diatas, hanya bedanya terleak pada usaha mengorek sumber perasaan yang menjdi beban tekanan batin klien serta mengaktifkan kekuatan tenaga kejiwaan klien (potensi dinamis) melalui pengertian tentang realitas situasi yang dialami olehnya, 6) Psychoanalysis Method, metode ini berpangkal pada pandangan bahwa semua manusia itu jika pikiran dan perasaannya tertekan oleh kesadaran dan perasaan atau motif-motif tertekan tersebut masih aktif mempengaruhi segala tingkah laknya meskipun mengendap di alam ketidaksadaran (Amin, 2013 : 69-74).

Dalam bukunya mengakatakan bahwa bimbingan dalam prakteknya diperlukan beberapa metode untuk memberikan arahan bagi siswa sebagai penunjang untuk melihat keberhasilannya dalam membimbing siswa. Adapun beberapa metode bimbingan dan konseling islam antara lain sebagai berikut: 1) Metode keteladanan, keteladanan pendidik adalah metode yang meyakinkan 
berhasil dalam setiap gerakan anak dalam mental spiritual. Hal ini karena guru merupakan contoh terbaik bagi anak didiknya. Disadari atau tidak disadari tindakan, tingkah laku seorang guru telah terletak dalam kejiwaan anak didiknya baik ucapan, perbuatan dan moral spiritual, 2) Metode pembiasaan, masalah yang sudah menjadi ketetapan dalam syariat islam bahwa anak diciptakan dalam keadaan tinta tauhid yang murni, agama ynag lurus dan iman kepada allah. Dari sini peran pembiasaan pengajaran dan pendidikan dalam pertumbuhan dan perkembangan anak dalam menemukan tauhid yang murni, 3) Metode nasihat, metode yang lain yang penting adalah pendidikan mental spiritual. Dengan nasihat dapat membuka mata anak untuk memahami hakikat sesuatu, sehingga memudahkan untuk memahami ajaran-ajaran prinsip islam, 4) Metode perhatian, mencurahkan perhatian terhadap kebiasaan perkembangan anak didik akan dapat membantu menumbuhkan akidah moral, dan merupakan persiapan moral spiritual, 5) Metode hadiah dan hukuman, dengan hukuman anak akan jera, berhenti dari perbuatan dan peka dalam menolak hawa nafsu, dengan ini akan terhindar dari kenistaan dan kemungkaran.

Dalam pembelajaran dikenal dengan sebutan mental discipline. Mental discipline adalah teori yang latihan khususnya menghasilkan perbaikan fungsi atau perbaikan umum pada kemampuan mental (mental ability). Kata disiplin semula disinonimkan dengan education (pendidikan), sedangkan dalam pengertian modern pengertian dasarnya adalah kontrol terhadap kelakuan, baik oleh suatu kekuasaan luar ataupun oleh individu sendiri. Jadi mental discipline berarti kontrol terhadap mental sehingga mempunyai kemampuan (Muhaimin, 2004:21).

\section{HASIL DAN PEMBAHASAN}

Hasil data yang didapat dari Tata Usaha di Ma'had Darul Arqam (Rabu, 07 Maret 2018) Nama dan identitasnya pesantren ini bernama Pondok Pesantren Darul Arqam Muhammadiyah Daerah Garut, Pesantren ini berlokasi di Jl. Ciledug No. 284/36 Rt. 01 Rw. 02 Desa Ngamplangsari Kecamatan Cilawu Kabupaten Garut - 44181.

Santri di Ma'had Darul Arqam seluruhnya berjumlah 1087 orang, diantaranya, santri tsanawiyah putra seluruhnya berjumlah 314 orang dan santri tsanawiyah putri berjumlah 321 orang, kemudian santri aliyah putra seluruhnya berjumlah 212 orang dan santri aliyah putri 240 orang.

Darul Arqam memiliki jadwal yang padat dalam dunia pendidikan, karena pembelajaran di Ma'had Darul Arqam dimulai dari jam 5 subuh setelah shalat subuh berjamah sampai akhir pembelajaran jam 9 malam. Adapun waktu istirahat yang diberikan yakni, ketika pagi jam 6-7 santri diberi waktu untuk sarapan di ruang makan dan mandi, kemudian pembelajaran dimulai lagi dan 
nanti bertemu istirahat jam 11.30 untuk melakukan shalat dzuhur berjama'ah dan makan siang setelah itu santri diberi waktu istirahat hingga tiba waktu ashar namun ada juga santri yang melakukan Ekskul (Ekstra Kulikuler) diwaktu istirahat tersebut dan kemudian mulai lagi pembelajaran setelah shalat ashar berjama'ah hingga waktu magrib tiba santri istirahat untuk makan malam dan shalat magrib berjama'ah, setelah tiba isya santri berjama'ah yang kemudian lanjut pembelajaran hingga jam 9 malam. Padatnya waktu pembelajaran yang dijadwalkan oleh Ma'had maka memerlukan tenaga pengajar yang banyak, sehingga total pendidik pelajaran keagamaan yang ada di Ma'had Darul Arqam berjumblah 53 orang pendidik, dan pendidik umum yang aktif mengajar berjumlah 48 orang pendidik, sehingga jika dijumlahkan seluruh pendidik yang aktif di Ma'had Darul Arqam mencapai 101 orang pendidik. Pendidik di Ma'had Darul Arqam rata-rata memiliki gelar sarjana, magister dan beberapa yang memiliki gelar doctoral. Pendidik di Ma'had Darul Arqam sebagian ada yang sudah diangkat menjadi PNS, namun tidak semua pendidik di Ma'had Darul Arqam PNS (Pegawai Negeri Sipil).

\section{Gambaran Santri dan Aturan di Darul Arqam}

Santri di Ma'had Darul Arqam seluruhnya berjumlah 1087 orang, diantaranya, santri tsanawiyah putra seluruhnya berjumlah 314 orang dan santri tsanawiyah putri berjumlah 321 orang, kemudian santri aliyah putra seluruhnya berjumlah 212 orang dan santri aliyah putri 240 orang.

Santri di Darul Arqam wajib mondok atau bertempat tinggal di lingkungan pesantren. Adapun lokasi asrama santri putra dan santri putri tidak saling berdekatan melainkan terpisahkan oleh beberapa lapang olahraga dan terpisah oleh rumah para pembina dan aparatur Ma'had. Adapun lokasi asrama santri tsanawiyah putra maupun putri tidak dicampurkan satu sama lain, melainkan asrama tsanawiyah dan aliyah diberi jarak. Adapun jarak dari asrama ke kelas atau tempat belajar santri itu dekat hanya ditempuh dengan berjalan kaki, baik untuk santri putra ataupun santri putri, namun kelas atau tempat belajar di Ma'had Darul Arqam dipisahkan antara kelas santri putra dan santri putri.

Berdasarkan hasil wawancara dengan Ibu Aas sebagai ketua Mahkamah, (Rabu, 07 Maret : 2018 ) Santriwati yang pesantren disana hampir merata yakni berasal dari daerah Garut, Bandung dan Jakarta namun ada beberapa santri yang berasal dari luar Jawa Barat atau luar Pulau Jawa, seperti Riau dan Palembang.

Orang tua santri yang bekerja sebagai pengusaha tentunya memiliki kesibukan yang berbeda, pengusaha identik lebih sibuk dibandingkan dengan orang tua yang bekerja sebagai Pegawai Negeri Sipil (PNS) sehingga santri merasa kurang mendapat perhatian dari orang tua. Orang tua percaya sepenuhnya kepada pembina dan pengurus santri di Ma'had. 
Santri yang baru masuk lebih mendapat perhatian dari orang tua dibandingkan santri yang sudah mondok selama satu tahun lebih, perhatian yang dimaksusd oleh peneliti yakni, dengan seringnya santri di kunjungi oleh orang tua, orang tua menelfon pembina lebih intens dan teratur untuk menanyakan perkembangan dan keadaan santri atau hanya untuk berbicang dengan anaknya. Namun, ketika santri sudah pesantren lebih dari satu tahun biasanya orang tua sudah membiarkan anaknya dan percaya kepada pihak Ma'had. Tidak sedikit santri di Darul Arqam yang mengalami Broken Home, sehingga santri mengalami masa sulit yang kemudian menjadikannya memuat masalah di Ma'had bahkan ada santri yang memang sengaja memuat sensasi selama di Ma'had, sperti terus sengaja melanggar aturan yang ada di Ma'had.

Adapun beberapa kenakalan yang kerap kali santri lakukan ialah masalah yang muncul dari diri sendiri dan termasuk kedalam pelanggaran ringan, seperti: 1) Kemalasan, beberapa santri malas untuk masuk sekolah ataupun malas untuk melakukan shalat berjamaah di masjid, 2) Kurang disiplin, kerap kali santri tidak memakai seragam yang sudah ditentukan oleh pihak Ma'had, atau perilaku tidak disiplin santri ketika di asrama biasanya santri tidak rapih dalam menyimpan barang pribadinya seperti sandal, sepatu, baju, handuk, dan barang lainnya. Sering kali santri tidak disiplin dalam masalah waktu, santri sering kali telat datang ke Ma'had dan tidak sesuai dengan izin waktu yang diberikan oleh Ma'had, 3) Berpakaian, seringkali santri putra dan putri melanggar aturan pondok yang sudah ada, seperti santri putra yang memakai celana pendek disekitar Ma'had dan memakai celana robek. Bagi santri putri kerap kali santri putri ada yang terlihat memakai celana ketat di lingkungan Ma'had.

Adapun Gambaran Aturan dan Sanksi di Pesantren Darul Arqam, pelanggaran dan sanksi di Pesantren Darul Arqam terbagi menjadi empat macam yakni ada aturan dan sanksi ringan, sedang, berat, dan khusus diantaranya sebagai berikut:

\section{Pelanggaran Ringan}

Pelanggaran ringan umumnya lebih sering dilakukan santri, baik itu santri yang tidak sengaja melanggar karena dengan alasan tidak tahu dan santri baru, adapun santri yang memang sengaja menggar aturan dan mengulang pelanggaran tersebut, adapun pelanggaran ringan diantaranya: Berambut panjang, Tidak mengembalikan surat izin, Berbuat keributan di asrama, Membuang sampah sembarangan, Shalat masbuk, Bercelana pendek, Tidak mengerjakan tugas harian, Tidur di asrama lain, Tidak berseragam dan bersepatu.

Adapun sanksi yang didapati setelah melakukan pelanggaran ringan, diantaranya: Shalat di shaf pertama, Tahfidz mufradat dan Menulis Al-Quran.

Pelanggaran Sedang 
Pelanggaran sedang biasanya dilakukan oleh santri yang sudah mondok lebih dari satu semester di Darul Arqam dan yang mendapat palanggaran berat biasanya santri yang sudah tercatat bahwa sebelumnya telah melanggar aturan Ma'had, adapun yang termasuk kedalam pelanggaran sedang diantaranya: Keluar tanpa izin, Tidak shalat berjama'ah di masjid, Menyalahgunakan surat izin, Corat-coret sembarangan, Memiliki dan menempelkan gambar yang tidak pantas, Berpakaian tidak menutupi aurat, Beraksesoris tidak pantas, Membawa kendaraaan bermotor, Membawa HP, TV, dan Radi, Begadang, Main di atas genting, Tidak memiliki buku cacatan dan buku wajib, Meninggalkan kelas tanpa keterangan, Mencat rambut, Makan diluar waktu dan tempat yang telah ditentukan, tidur satu ranjang berdua, Berkepang, Menghilangkan buku pegangan tanpa sengaja

Adapun sanksi dari santri yang mendapati pelanggaran sedang, diantaranya: Kultum, Adzan di tempat umum dan Membersihkan ruangan.

Pelanggaran Berat

Pelanggaran berat yaitu pelanggaran yang sudah mencapai melanggar hukum dan bersangkutan dengan pihak kedua atau pihak lain, adapun yang termasuk pelanggaran berat diantaranya: Menyalahgunakan infak bulanan, Berkhalwat, Merokok, Mencuri, Berkelahi, Memalak, Melakukan penganiayaan, Berkata kotor dan kasar, Bertato, Mutasyabih, Merusak barang milik orang lain dan atau pesantren, , Putra masuk ke asrama putri atau sebaliknya, Menghilangkan buku pegangan dengan secara sengaja.

Adapun sanksi yang didapati setelah melakukan pelanggaran berat, diantaranya: Digunduli, Skorsing, Dikeluarkan dengan hormat, Dikeluarkan tidak hormat dan Pelanggaran Khusus. Pelanggaran khusus merupakan pelanggaran yang sudah tidak bisa mendapat toleransi dari pihak Ma'had, adapun pelanggaran yang dimaksud antara lain: Melakukan pengeroyokan, Minum khamr, narkoba, judi dan zina.

Adapun sanksi yang didapati setelah melakukan pelanggaran khusus, yaitu: Dikeluarkan secara tidak hormat

Adapun ketentuan untuk memproses pemberian sanksi kepada santri, diantaranya: 1) Melakukan pelanggaran ringan sebanyak satu kali santri hanya mendapat peringatan 2) Melakukan pelanggaran ringan lebih dari tiga kali dikenakan sanksi kategori sedang 3) Melakukan pelanggaran sedang lebih dari tiga kali dikenakan sanksi yang dilategorikan berat 4) Dan setiap melakukan pelanggaran berat diharuskan menandatangani surat pernyataan yang diketahui orang tua santri.

Tujuan dari adanya aturan dan sanksi di Darul Arqam adalah untuk membimbing santrinya supaya tetap berada dalam jalan yang benar. Bimbingan keagamaan adalah segala kegiatan yang dilakukan oleh seseorang dalam rangka memberikan bantuan kepada orang lain yang mengalami kesulitan-kesulitan 
ruhaniah dalam lingkungan hidupnya agar orang tersebut mampu mengatasinya sendiri karena timbul kesadaran dan penyerahan diri terhadap kekuasaan tuhan yang Maha Esa, sehingga timbul pada diri pribadinya suatu cahaya harapan kebahagiaan hidup masa sekarang dan masa depannya, (Amin, 2013 : 19)

\section{Proses Bimbingan Keagamaan melalui Program Mahkamah terhadap Kedisiplinan Santri di Darul Arqam}

Metode nasihat diberikan kepada santri yang melanggar aturan, dengan nasihat pembina maka dapat membuka mata santri untuk memahami hakikat sesuatu, sehingga memudahkan untuk memahami ajaran-ajaran prinsip islam. Metode ini digunakan kepada seluruh pelanggaran yang dilakukan oleh santri, baik pelanggaran ringan, sedang atupun berat.

Selain metode nasihat, Mahkamah juga menggunakan metode konseling, dimana metode ini dimaksudkan untuk mengarahkan dan membimbing namun metode ini bertujuan supaya proses bimbingan tidak hanya dilakukan dengan komunikasi satu arah melainkan supaya terjadinya komunikasi dua arah. Hal ini merupakan hal penting dimana santri yang melanggar aturanpun memiliki hak untuk didengar atas hal apa yang ingin disampaikannya.

Metode al-Targhib dan al-Tahdzib atau disebut dengan metode ujian dan hukuman ini terdiri atas dua metode sekaligus yang berkaitan satu sama lain alTarghib dan al-Tahdzib. Targhib adalah janji-janji disertai bujukan agar seseorang senang melakukan kebaikan dan menjauhi kejahatan. Tahdzib adalah ancaman untuk menumbuhkan rasa takut berbuat tidak benar atau disebut jera. Tekanan metode targhib terletak pada harapan untuk melakukan kebajikan sementara metode tahdzib terletak pada upaya untuk menjauhkan dari kejahatan atau dosa. Ma'had memberikan metode ini bertujuan supaya santri yang melanggar aturan merasa jera dan tidak akan mengulangi kesalahan untuk yang kedua kali atau seterusnya, namun hukuman yang diberikan kepada santri tidak lah berupa hukuman Ta'zir melainkan hukuman yang bersangkutan dengan eagamaan. Maka disana pengurus mahkamah membuat janji-janji dengan santri melalui Surat Pernyataan yang di Tanda tangani oleh santri yang melanggar aturan dan pengurus yang terait juga memberikan hukuman atau sanksi kepada santri yang melanggar aturan, namun hukuman yang diberikan kepada santri bukanlah hukuman yang dilakukan dengan kekerasan akan tetapi santri diberikan hukuman berupa bimbingan keagamaan dan yang bermanfaat bagi santri itu sendiri, seperti misalnya harus shalat di shaf pertama.

Berdasarkan hasil wawancara dengan Ibu Aas sebagai ketua Mahkamah, (Rabu, 07 Maret : 2018 ) Mahkamah mensosialisasikan atau menyampaikan informasi mengenai aturan Ma'had berikut dengan sanksi yang akan diberikan oleh pihak mahkamah disampaikan kepada santri baru baik secara langsung juga 
secara tidak langsung yakni melalui buku saku yang diberikan kepada seluruh santri di hari pertama santri masuk Ma'had. Yang dimaksud dengan buku saku, yakni buku pegangan yang dimiliki seluruh santri yang berisi mengenai aturanaturan Ma'had berikut dengan sanksi kemudian buku saku dilengkapi atau berfungsi sebagai surat izin santri untuk keluar Ma'had, baik untuk izin libur setiap minggu ataupun untuk izin setiap libur bulanan.

Adapun proses bimbingan keagamaan yang diberikan mahkamah kepada santri yang melanggar aturan yakni berdurasi 15-30 menit di ruang atau kantor mahkamah, kemudian jika pelanggaran yang dilakukan berupa pelanggaran ringan atau sedang durasi bimbingan juga sanksi yang diberikan ialah selama satu minggu. Selama satu minggu santri akan diawasi oleh petugas mahkamah baik yang terkait untuk melakukan bimbingan ataupun diawasi atas berjalannya sanksi yang diberikan. Namun jika pelanggaran berat yang dilakukan oleh santri maka bimbinganpun akan berbeda, bimbingan akan berlanjut dengan jangka yang lebih panjang dan santri akan dipanggil ke rumah pembina yang terkait ataupun dipanggil oleh kepala sekolah dan bahkan akan dilakukan memuat Surat Pernyataan yang harus di tanda tangani orang tua yang dipanggil oleh pihak Ma'had. Kemudian ketika terjadi kasus santri yang melakukan pelanggaran terus berulang atau melakukan pelanggaran yang lebih berat maka pihak mahkamah akan melakukan skorsing terhadap santri sesuai dengan sanksi yang tertulis di buku saku santri.

Santri yang melanggar aturan Ma'had akan di proses melalui mahkamah akan tetapi santri yang melanggar aturan tidak langsung dijatuhi sanksi tapi melalui propses, ada tiga tahap dalam proses mahkamah ini, diantaranya:

Pertama, Tahap ringan yaitu santri yang melanggar aturan ringan hanya mendapat sebuah peringatan dari pihak mahkamah. Dalam tahap ini santri akan dipanggil melalui pusat informasi Ma'had untuk mendangi kantor mahkamah kemudian santri akan mendapat bimbingan juga diberi peringatan dan santri akan diberi selembar berita acara untuk di tulis dan ditanda tangan sebagai bukti dan pembukuan bahwa santri telah mendapat peringatan dari mahkamah. Dalam tahap ringan santri yang melanggar untuk yang pertama kali tidak akan di berikan sanksi apapun, melainkan hanya bimbingan serta peringatan langsung dari petugas piket mahkamah.

Kedua, Tahap sedang yaitu tahap sedang biasanya diberikan kepada santri yang melanggar aturan dan sudah mendapat peringatan dari mahkamah sebanyak 2-3 kali. Ditahap sedang ini santri baru akan diberikan sanksi berupa sanksi sedang. Dalam tahap ini santri akan dipanggil secara umum melalui pusat informasi Ma'had untuk mendangi kantor mahkamh kemudian proses pemberian bimbingan berikut sanksi akan diberikan, namun ketika pelanggaran diulang beberapa kali maka pihak mahkamah sebagai petugas kedisiplinan di Ma'had akan memberi selembar SP (Surat Pernyataan) dimana SP ini ditulis 
tangan oleh santri yang melanggar dan berisi mengenai pelanggaran yang dilakukan oleh santri itu berikut dengan waktu dan keterangan lainnya yang berkaitan dengan pelanggaran tersebut juga lengkap dengan tanda tangan santri dan pembina. Dalam tahap sedang santri akan diberikan sanksi, adapun danksi yang diberikan berupa menulis Al-Quran, shalat di shaf pertama, ataupun khutbah di mimbar masjid.

Ketiga, Tahap berat yaitu tahap berat diberikan kepada santri yang melanggar atuan berat atau santri telah mendapat beberapa kali peringatan dan pernah mendapat hukuman sedang maka santri akan diberi sanksi berat. Dalam pelanggaran berat ini santri diberikan SP (Surat Pernyataan) seperti santri yang melanggar aturan sedang namun bedanya SP yang diberikan kepada santri yang melanggar aturan berat ini SPnya disertai tanda tangan orang tua santri yang dipanggil oleh pihak ma'had, baik itu pembina ataupun bisa langsung ditangani oleh pihak kepala sekolah. Dalam tahap berat santri yang melanggar akan diberikan sanksi berupa skorsing atau dikeluarkan secara hormat oleh pihak Ma'had.

Santri yang melanggaran aturan khusus sudah bukan lagi urusan pihak mahkamah, namun hal itu akan melibatkan aparatur tinggi di Ma'had seperti kepala sekolah dan akan menjadi keepakatan bersama dalam penyelesaiannya. Dalam hal ini santri yang melanggar aturan khusus tidak mendapat toleransi dan akan dikeluarkan secara tidak hormat dari pihak Ma'had.

Dalam melakukan tindakan penghukuman santri di Ma'had Darul Arqam adalah salah satu cara mendidik anak, seperti yang dikatakan oleh K.H. Hasyim Asy'ari mengutarakan dalam buku bahwa metode bimbingan keagamaan untuk menumbuhkan akhlak santri ada lima metode yang diterapkan di pesantren yaitu metode keteladanan (Uswatun Hasanah), latihan dan pembiasaan mengambil pelajaran (Ibrah), nasehat (Mauidlah), kedisiplinan, ujian dan hukuman (Targhib wa Tahzib) (Tamyiz, $2001: 5$ )

\section{Hasil Bimbingan Keagamaan melalui Program Mahkamah terhadap Kedisiplinan Santri di Darul Arqam}

Santri yang melanggar aturan dan mendapatkan bimbingan di mahkamah tidaklah sama, namun kenyataanya santri yang diberikan bimbingan beragam. Banyak faktor yang memuat santri beragam ketika mendapatkan bimbingan, misalnya: faktor dari kebiasaan santri di rumah sebelum masuk pesantren dan pergaulan santri di Ma'had. Dengan begitu hasil dari bimbingan keagamaan yang dilakukan mahkamah berbeda-beda.

Untuk mencapai keberhasilan dalam menjalankan proses mahkamah ini seperti yang telah dipaparkan diatas hampir sama dengan konsep yang diungkapkan (Abdullah Nashih, 1996: 47 ) Metode untuk memberikan arahan 
bagi siswa sebagai penunjang untuk melihat keberhasilannya dalam membimbing siswa. (1) Metode keteladanan, keteladanan pendidik adalah metode yang meyakinkan berhasil dalam setiap gerakan anak dalam mental spiritual. Hal ini karena guru merupakan contoh terbaik bagi anak didiknya. (2) Metode pembiasaan, masalah yang sudah menjadi ketetapan dalam syariat islam bahwa anak diciptakan dalam keadaan tinta tauhid yang murni, agama ynag lurus dan iman kepada allah. 3) Metode nasihat, metode yang lain yang penting adalah pendidikan mental spiritual. Dengan nasihat dapat membuka mata anak untuk memahami hakikat sesuatu, sehingga memudahkan untuk memahami ajaranajaran prinsip islam. (4) Metode perhatian, mencurahkan perhatian terhadap kebiasaan perkembangan anak didik akan dapat membantu menumbuhkan akidah moral, dan merupakan persiapan moral spiritual. (5) Metode hadiah dan hukuman, dengan hukuman anak akan jera, berhenti dari perbuatan dan peka dalam menolak hawa nafsu, dengan ini akan terhindar dari kenistaan dan kemungkaran.

Adapun santri yang dimaksud beragam ialah, ada santri yang sudah beberapa kali mendapat bimbingan bahkan mendapat SP (Surat Pernyataan) oleh mahkamah tetap melakukan pelanggaran yang sama, ada pula santri yang beberapa kali mendapat bimbingan oleh mahkamah tetapi dengan pelanggaran yang dilakukan berbeda-beda, dan ada juga santri yang sekali mendapat bimbingan oleh mahkamah tetapi dia jera dan tidak mau melakukan pelanggaran untuk yang kedua kalinya.

Beberapa santri ketika dia dipanggil oleh mahkamah untuk mendapatkan bimbingan, dia sadar dengan sendirinya atas dasar apa ia mendapatkan bimbingan dari mahkamah maka disana pengurus mahkamah tidak perlu lagi untuk menyadarkan santri atas pelanggaran yang diperbuatnya, ada juga santri yang sesampainya dikantor mahkamah ia seperti tidak melakukan kesalahan apapun berarti disana santri belum ada kesadaran atas pelanggaran yang santri perbuat yang kemudian disanalah santri diberi pengarahan dan bimbingan secara langsung oleh petugas piket mahkamah.

Perubahan yang terjadi setelah santri mendapatkan bimbingan berikut dengan sanksi yang diberikan pihak mahkamah itu lansung, santri yang melannggar peraturan akan langsung berubah dan langsung juga menjalankan sanksi yang diberikan keapadanya, kemudian santri ada yang jera kemudian menjalankan kehidupan teratur dan disiplin, namun ada juga santri yang beberapa bulan kemudian lupa atas apa yang didapatkan dari bimbingan dan mengulangi kesalahan yang sama.

Berdasarkan hasil wawancara dengan santri X putri Darul Arqam kelas VII (Minggu, 11 Maret : 2018) X mengaku bahwa telah mendapatkan bimbingan selama enam kali dari mahkamah. Pelangaran yang Ia perbuat ialah merupakan pelanggaran ringan dan ia mendapatkan sanksi dari pihak mahkamah setelah 
ketiga kali mendapat peringatan, Ia mendapatkan sanksi berupa wajib shalat di shaf pertama selama satu bulan penuh dan Ia selama satu bulan penuh menjalankan shalat lima waktu berada di shaf pertama dan harus mendapat tanda tangan imam sebagai bukti telah menjalankan sanksinya. Namun dapat dilihat dari pengakuan Ica yang mengulang pelanggaran untuk yang kedua bahkan ketiga kalinya, Ia tidak merasa jera atas bimbingan dan sanksi yang Ia dapatkan.

Berdasarkan hasil wawancara dengan santri X putri Darul Arqam kelas IX (Minggu, 11 Maret : 2018) X merupakan santri yang mondok di Darul Arqam hampir tiga tahun lamanya, menurut pengakuan Ia pernah mendapatkan bimbingan dari mahkamah sebanyak 8 kali dan pelanggaran yang Ia perbuat berbeda-beda, dimulai dari pelanggaran ringan, sedang, hingga berat pernah ia lakukan begitupun dengan sanksi yang Ia dapatkan, pernah mendapat sanksi ringan, sedang dan berat, bahkan SP (Surat Pernyataan) pernah Ia dapatkan hingga pemanggilan orang tua. Pengakuan Gahara ini Ia merasa jera atas bimbingan juga sanksi namun mungkin Ia sedang berada di masa ingin mencoba hal-hal yang baru. Ia juga pernah dipanggil ke Ruang BK (Bimbingan Konseling) atas pelanggaran yang Ia perbuat dan menurut dia mendapat bimbingan di Ruang BK lebih baik dan masuk sehingga membuatnya sadar dibandingkan ketika Ia mendapat bimbingan di mahkamah.

Hasil wawancara dengan santri X putri Darul Arqam kelas IX (Minggu, 11 Maret : 2018) X mengakuan pernah masuk mahkamah sebanyak dua kali dan keduanya merupakan pelanggaran ringan, bahkan pelanggaran yang satunya ialah pelanggaran yang dilakukan oleh seluruh penghuni asrama yang ia tinggali. Ia mengaku jera atas bimbingan dan sanksi yang Ia dapatkan sehingga Ia tidak mau lagi mengulangi perbuatan salahnya.

Hasil wawancara dengan Ibu Reni sebagai anggota mahkamah dan pembina santri aliyah (Rabu, 07 Maret : 2018) menurut beliau hasil dari keefektifan mahkamah ialah fifty-fifty maksudnya seimbang antara santri yang jera dan santri yang tidak jera. Menurut beliau ada santri yang memang panut yang mudah untuk diarahkan dan ada juga yang tidak, santri yang termasuk tidak panut menurutnya bukan berarti santri itu tidak jera melainkan memang santri itu dimana mereka sedang memasuki masa remaja dimana masa remaja adalah masa yang sedang merasa ingin mencoba segala hal yang menurutnya baru, maka dari itu ada santri yang terus menerus dipanggil pihak mahkamah untuk mendapat bimbingan. Bukan berarti ketika santri ingin mencoba segala hal itu dibiarkan begitu saja, namun disanalah diperlukannya pengarahan dan bimbingan sehingga pentingnya mahkamah bagi para santri yang ada di Darul Arqam. 
Adapun hasil dari bimbingan keagamaan melalui program mahkamah ini, santri terbagi menjadi tiga kategori, 1) Santri yang telah mendapat bimbingan menjadi jera dan tidak mengulangi kesalahan atau tidak melnggar aturan pondok 2) Santri yang telah mendapat bimbingan menjadi jarang melakukan pelanggaran, akan tetapi terkadang maasih melakukan pelanggaran. 3) Adapun santri yang telah mendapat bimbingan tetap melakukan pelanggaran dan tidak merasa jera sama sekali.

Untuk melihaat keberhasilan dalam program mahkamah maka seharusnya diselaraskan dengan tujuan yang ada. Tujuan bimbingan dan konseling keagamaan islami adalah, sebagai berikut: Membantu individu/kelompok individu mencegah timbulnya masalah-masalah dalam kehidupan keagamaan, antara lain dengan cara: 1) Membantu individu menyadari fitrah manusia 2) Membantu individu mkengambangkan fitrahnya (mengaktualisasikannya) 3) Membantu individu memahami dan menghayati ketentuan dan petunjuk Allah dalam kehidupan keagamaa 4) Membantu individu menjalankan ketentuan dan petunjuk Allah mengenai kehidupan keagamaan (Faqih, 2001 : 61-62).

\section{PENUTUP}

Program mahkamah merupakan layanan bimbingan dan konseling yang berbasis keagamaan. Tujuan dari program mahkamah ialah membina dan mendidik santri agar senantiasa berada dalam jalan lurus dan disiplin, serta dapat membina para santri dalam mengatasi permaslahannya dengan cara diberikan bimbingan keagamaan. Untuk mencapai kesempuranaan tujuan Ma'had, khususnya mahkamah yang diberikan peran untuk mengatasi permaslahan-permasalahan santri, anggota dan petugas mahkamah diberi tuntutan memiliki metode dan strategi melalui bimbingan keagamaan.

Mengatasi masalah-masalah kenakalan santri di Ma'had Darul Arqam telah disepakati dengan menerapkan bimbingan keagamaan melalui sebuah program yakni program mahkamah. Program mahkamah merupakan sebuah program yang diturunkan dari visi dan misi Ma'had serta untuk mencapai tujuan yang dicita-citakan oleh Ma'had Darul Arqam. Semua diberikan perlakuan yang sama dan tanpa terkecuali, tidak ada perbedaan antara santri baru atau tsanawiyah dan santri aliyah.

Program mahkamah yang berada di Ma'had Darul Arqam ini termasuk kedalam irsyad. Dimana irsyad dalam Islam lebih mengarah kepada proses internalisasi dan transmisi ajaran Islam. Fokus kegiatannya dapat berupa : (1) ibda bi al-nafs, dzikr Allah, du'a, wiqâyat al-nafs, tazkiyyat al-nafs, shalat dan shaum ; (2) ta'lim, tawjih, mau'izhah dan nashihah ; (3) Isytisyfa.

Adapun aturan yang terdapat, diantaranya: Berambut panjang atau diwarnai, Tidak izin keluar Ma'had, Sholat Masbuk, Memakai celana pendek, Tidak memakai seragam atau sepatu, Merokok, dan Berkhalwat. 
Adapun hukuman yang didapatkan oleh santri yang melanggar, diantaranya: Shalat di shaf pertama, Membersihkan ruangan, Tahfidz mufradat, Kultum dan Skorsing.

Dari pelanggaran yang santri lakukan sampai mendapat hukuman dari Mahkamah, maka hasil penelitian dapat disimpulkan terbagi menjadi tiga, yaitu : 1) Kondisi santri yang melakukan pelanggaran dan memiliki masalah akan mendapatkan perlakuan khusus yakni dengan mendapatkan bimbingan keagamaan di mahkamah. Diberikan suatu hukuman yang berkaitan dengan keagamaan, seringkali menjadi pembelajaran santri agar menjadikan santri tidak mengulang perbuatan yang dianggap tercela atau dengan kata lain agar memberikan efek jera terhadap santri dan santri tetap disiplin. 2) Proses pemberian bimbingan memiliki tahapan-tahapan yang diberikan mahkamah terhadap santri yang melanggar aturan terbagi menjadi tiga tahap, yakni; tahap ringan, dimana santri hanya diberi bimbingan selama lima menit dan diberi peringatan oleh petugas piket mahkamah, tehap sedang, dimana santri akan diberikan bimbingan disertai pemberian hukuman ringan, kemudian yang terakhir tahap berat, dimana santri akan diberikan bimbingan disertai hukuman berat yang disesuaikan dengan pelanggaran yang dilakukan santri. 3) Adapun hasil dari bimbingan keagamaan melalui program mahkamah ini, santri terbagi menjadi tiga kategori: pertama, Santri yang telah mendapat bimbingan menjadi jera dan tidak mengulangi kesalahan atau tidak melnggar aturan pondok. Kedua, Santri yang telah mendapat bimbingan menjadi jarang melakukan pelanggaran, akan tetapi terkadang maasih melakukan pelanggaran. Ketiga, Adapun santri yang telah mendapat bimbingan tetap melakukan pelanggaran dan tidak merasa jera sama sekali.

\section{DAFTAR PUSTAKA}

Amin, S. M (2012). Bimbingan Dan Konseling Islam. Jakarta: Amzah.

Arifin, I. Z. (2008). Bimbingan dan Konseling Islam (Al-Irsyad Wa Altawjîh AlIslam) Berbasis Ilmu Dakwah dalam Ilmu Dakwab: Academic Journal for Homiletic Studies 4(11), 383-3896-1.

Faqih, A. R. (2001). Bimbingan dan Konseling dalam Islam. Yogyakarta: UIIpress

Haderani,H dkk.,(2014). Peran Guru Pendidikan Agama Islam dalam

Kegiatan Bimbingan Keagamaan pada Sekolah Menengah Pertama

Negeri 23 Banjarmasin. Jurnal Tashwir.2(4

Kusnadi, Edy.(2014). Pola Bimbingan Konseling Agama Islam Pada Pasien

Rawat Inap. Media Akademika.29(1)

Muhaimin. (2004). Paradigma Pendidikan Islam Upaya Mengefektiflean Pendidikan Agama Islam di Sekolah. Bandung: PT. Remaja Rosdakarya

Mustafidah, dkk. (2008). Representasi Kasus Menggunakan Inductive Retrieval 
N. Rahmatunisa, D. Kuswana, A. Saefulrohim

Dengan Algoritma C4.5 Pada Kasus Klasifikasi Prestasi Mahasiswa Berdasarkan Nem, Tingkat Kedisiplinan, Dan Motivasi dalam Biomath 9 (2)

Nurihsan, A. J. (2006). Bimbingan Dan Konseling. Bandung: Refika Aditama

Octaviani, E.,D., dkk (011) Religiusitas Dan Kedisiplinan Pada Anggota Polri dalam Jurnal Psikologi Proyeksi 6, (2)

Prayitno, (2004). Layanan Bimbingan Kelompok dan Konseling Kelompok. Padang: UNP.

Saepulrohim, A. (2016). Manajemen Bimbingan dan Konseling Islam. Bandung: Mimbar Pustaka

Sugiyanto, Zaenal,Suharyo.(2011).Analisis Praktik Pendidikan Kesehatan Reproduksi Remaja Oleh Guru Bimbingan dan Konseling pada SMP yang Berbasis Agama di Kota Semarang dalam Jurnal Dian 11(1).

Ulwan, A. N. (1996). Pendidikan Anak Dalam Islam (Pendidikan Sosial Anak). Bandung: Remaja Rosda Karya.

Yuliejantiningsih, Y., (2012). Pengaruh Fungsi Pengendalian Oleh Kepala Sekolah Terhadap Disiplin Siswa Jurnal Manajemen Pendidikan. 1(1) 